\title{
R15 - DEVELOPMENT OF A SENSITIVITY AND COST-EFFECTIVE REAL TIME PCR: MEASURING A WIDE RANGE OF HBV DNA CONCENTRATIONS
}

$\underline{\text { Alcione de Oliveira dos Santos }}^{12}{ }^{3}$, Luan Felipo Botelho de Souza ${ }^{2}{ }^{3}$, Lourdes Maria Borzacov $^{23}$, Juan Miguel Villalobos-Salcedo ${ }^{12}$, Deusilene Souza Vieira 123.

1. Fundação Oswaldo Cruz Rondônia, Brazil - FIOCRUZ-RO; 2. Centro de Pesquisa em Medicina Tropical de Rondônia, Brazil - CEPEM; 3. Universidade Federal de Rondonia, Brazil - UNIR

Objectives: Several types of assays for detection and quantification are currently in use with a different effectiveness. The aim of this study was to develop an in house real-time PCR based method, which was both ultra-sensitive and efficient offering an alternative method for nucleic acid testing (NAT).

Methods: A precore fragment with $109 \mathrm{bp}$ was cloned and serial diluted to standard curve construction. The calibration of the HBV - DNA values was performed against OptiQuant ${ }^{\circledR}$ HBV-DNA Quantification Panel, Acrometrix Europe B.V.). Specifically, serial dilutions of the standard ranging from $2 \times 10^{2}$ to $2 \times 10^{6}$ were tested. Based on a linear regression, a conversion formula was calculated for the in -house measurements (copies/mL) to the international standard units $(\mathrm{IU} / \mathrm{mL})$. The correlation between Acrometrix kit and in house assay was performed by Pearson's test, using GraphPad 5.0 to fit regression lines between $\mathrm{IU} / \mathrm{mL}$ and copies $/ \mathrm{mL}$.

Results: Our method had an efficiency of $94.06 \%$ and showed good correlation with the leading international, WHO-approved test: AcroMetrix ${ }^{\circledR}$ HBV-DNA, $r=0.998, p$ $<0.0001$. Our test proved to be 100 times more sensitive than the commercially available AcroMetrix ${ }^{\circledR}$ kit, allowing detection of as little as two copies per ml of serum from HBVinfected individuals. The limit of detection for the commercial WHO-approved kit is 200 $\mathrm{IU} / \mathrm{ml}(2.3 \log 10 \mathrm{IU} / \mathrm{ml})$ while our qHBVRO test detected $0.0010 \mathrm{IU}(-2.9 \log 10 \mathrm{IU} / \mathrm{ml})$, which equates to 2 copies $/ \mathrm{ml}$ where $1 \mathrm{IU} / \mathrm{ml}=2000 \mathrm{copies} / \mathrm{ml}$. The qHBVRO assay was highly reproducible with intra- and inter-experimental coefficients of variation of $0-1 \%$. 
The analytical specificity of the test was investigated using samples from individuals that tested positive, negative and indeterminate for HBV surface antigen (HBsAg) by ELISA suggesting that qHBVRO PCR assay can detect HBV DNA in individuals with hepatitis $\mathrm{B}$ at any stage of the disease, qualifying it as an important alternative to other NATs.

Conclusion: The method proved to be efficient, sensitive, specific and reproducible detection of ocult HBV, and could be used for nucleic acid testing (NAT). 